\title{
Environmental impacts of genetic improvement of growth rate and feed conversion ratio in fish farming under rearing density and nitrogen output limitations
}

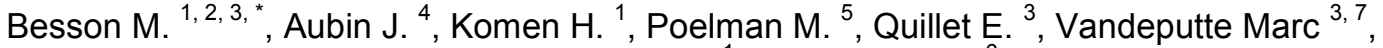 \\ Van Arendonk J.A.M. ${ }^{1}$, De Boer I.J.M. ${ }^{6}$
}

\footnotetext{
${ }^{1}$ Animal Breeding and Genomics Centre, Wageningen University, PO Box 338, 6700 AH Wageningen, the Netherlands

${ }^{2}$ AgroParisTech, UMR1313 Génétique Animale et Biologie Intégrative, 16 Rue Claude Bernard, 75231

Paris 05, France

${ }^{3}$ INRA, UMR1313 Génétique Animale et Biologie Intégrative, Allée de Vilvert, 78350 Jouy-en-Josas,

France

${ }^{4}$ INRA, Agrocampus Ouest Rennes, UMR1069 Sol Agronomie Spatialisation, 65 Rue de Saint Brieuc, 35042 Rennes, France

5 IMARES, Wageningen UR, Korringaweg 5, 4401 NT Yerseke, the Netherlands

${ }^{6}$ Animal Production Systems Group, Wageningen University, P.O. Box 338, 6700 AH Wageningen, the

Netherlands

${ }^{7}$ IFREMER, Chemin de Maguelone, 34250 Palavas-les-Flots, France

* Corresponding author : M. Besson, Tel.: +31 317482335. ; email address : mathieu.besson@wur.nl
}

\begin{abstract}
:
Today, fish farming faces an increasing demand in fish products, but also various environmental challenges. Genetic improvement in growth rate and feed conversion ratio is known to be an efficient way to increase production and increase efficiency in fish farming. The environmental consequences of genetic improvement in growth rate and feed conversion ratio, however, are unknown. In this study, we investigated the environmental consequences of genetic improvement in growth rate and feed conversion ratio in an African catfish farm, using Recirculating Aquaculture System (RAS). In RAS, total fish production of the farm is limited by rearing density or by the capacity to treat dissolved nitrogen. To evaluate the environmental consequences of genetic improvement in growth rate and feed conversion ratio, we combined life cycle assessment and bioeconomic modelling of genetic response to selection. We explored different impact categories, such as climate change, eutrophication, acidification and energy use, and we expressed impacts per ton of fish produced. Results show that the environmental impact of genetic improvement in growth rate and feed conversion ratio varies among impact categories and depends on the factor limiting production at farm level (i.e. rearing density or nitrogen treatment capacity). Genetic improvement of feed conversion ratio reduces environmental impacts in each scenario tested, while improving growth rate reduces environmental impacts only when rearing density limits farm production. Environmental responses to genetic selection were generally positive and show similar trends as previously determined economic responses to genetic improvement in growth rate and feed conversion ratio in RAS. These results suggest that genetic improvement of growth rate and feed
\end{abstract}


conversion ratio for species kept in RAS will benefit both the environmental impacts and the economics of the production system.

\section{Highlights}

- We combined a bioeconomic model and a life cycle assessment. We estimated the environmental impacts of genetic improvement in fish farming. I Improving growth keeps environmental impacts constant in nitrogen limiting condition. Improving feed conversion ratio always decreases environmental impacts. We observed that decreasing environmental impacts could increase farm profitability.

Keywords : life cycle assessment, African catfish, feed efficiency, recirculating aquaculture system, selection, thermal growth coefficient 


\section{Introduction}

2 Fish farming is the fastest growing animal food-producing sector in the world, due to the joint

3 effect of an increase in demand of fish products and a stagnation of fisheries captures (FAO,

4 2012). Fish farming, however, also faces some environmental challenges, such as

5 eutrophication resulting from emission of pollutants during fish rearing and the use of natural

6 resources for feed (Folke et al., 1994; Naylor et al., 2000; Read and Fernandes, 2003).

7 Previous life cycle assessments (LCA) showed that production of feed and fish farming are chain stages that contribute most to environmental impacts of fish farming (Aubin et al., 2006; Pelletier et al., 2009). Several studies have investigated the potential of alternative feed compositions (Boissy et al., 2011; Papatryphon et al., 2004; Pelletier and Tyedmers, 2007) or

11 alternative rearing systems (Aubin et al., 2009; Ayer and Tyedmers, 2009; d'Orbcastel et al., 2009) to reduce the environmental impact. These studies found trade-offs between different environmental impacts, such as climate change and eutrophication, when changing feed composition or rearing conditions.

Genetic improvement has potential to reduce various environmental impacts simultaneously but this aspect of selective breeding has not been explored so far in fish production. In many fish species, genetic response to selective breeding is high due to high heritability of commercial important traits, high intensity of selection and high genetic variation (Gjedrem et al., 2012). Genetic improvement, obtained through selective breeding programs, is a powerful tool to generate cumulative change in animal population. A genetic change in fish

21 performances is expected to improve not only economic benefit of farms (Besson et al., 2014;

22 Ponzoni et al., 2007), but to reduce also environmental impacts, as shown in livestock (Bell et 23 al., 2011; Buddle et al., 2011). Wall et al. (2010) suggested to evaluate these environmental 24 impacts of genetic improvement by calculating environmental values (ENV), based on the 25 principle of economic values (EV) from Hazel (1943). These environmental values express 
1 the difference in environmental impacts between a base situation and a situation with genetic

2 improvement in one trait while keeping the other traits constant (Groen, 1988). From the

3 whole farm perspective, genetic improvement in a trait can alter feeding strategy,

4 management practices and also purchase of inputs like feeds (van Middelaar et al., 2014).

5 Moreover, the impact of genetic improvement on farm management changes according to the

6 factor limiting production at farm level (Gibson, 1989; Groen, 1989). Evaluating the

7 environmental impact of genetic improvement requires, therefore, (1) to model the whole

8 farm, using, for example, a bio-economic model and (2) to evaluate the environmental impact

9 of changes at farm level, which can be performed using LCA.

Van Middelaar et al. (2014) combined bioeconomic farm modelling with an LCA to calculate

11 EV and ENV in dairy production. They found that genetic improvement of milk yield and

12 longevity increased economic benefit at farm level and decreased greenhouse gas (GHG) emissions along the production chain of one ton of fat-and-protein-corrected milk (FPCM). In fish farming, we developed a bioeconomic model for a farm producing African catfish (Clarias gariepinus) in recirculating aquaculture system (RAS) and investigated the EV of growth rate and feed conversion ratio (Besson et al., 2014). Growth rate and feed conversion ratio are considered key production parameters by fish farmers. In Besson et al. (2014), we showed that genetic improvement of both traits could increase farm income by improving the production of the farm and/or by improving production efficiency (fish produced per unit of on farm income depends on the trait and on the factor limiting the production of the farm: the capacity of the bio-filter to treat nitrogen or the maximum rearing density in the system studied.

24 Changes in production and production efficiency are expected to decrease environmental impacts also, by diluting fixed environmental impacts over more fish produced and by 
1 reducing the use of feed per ton of fish produced (Wall et al., 2010). In fish farming, however,

2 the impact of genetic improvement on the direction and on the magnitude of a change in

3 environmental impacts is not known. Moreover, possible synergies or trade-offs between EV

4 and ENV are unknown. In this study, therefore, environmental values of growth rate and feed

5 conversion ratio of African catfish reared in a RAS were calculated by combining the

6 bioeconomic model developed in Besson et al. (2014) with an LCA of fish production.

7

8

9

10

\section{Method}

\subsection{Bioeconomic model}

The bioeconomic model used in this study was developed in Besson et al. (2014) using R ( R Development Core Team, 2008). This model describes a RAS producing 500 tons of African catfish per year. Tanks are restocked after fishing all along the year and during a one year period, the model assumes that all stocked fish have a common genetic value. The model was based on information provided by private companies. The RAS was composed of four main compartments: (1) a series of 20 rearing tanks ( 6 tanks of $6 \mathrm{~m}^{3}$ for fish from 13 to $80 \mathrm{~g}$ and 14 tanks of $50 \mathrm{~m}^{3}$ for fish from 80 to $1300 \mathrm{~g}$ ), (2) a mechanical filter, which remove solid waste, (3) a bio-filter where nitrifying bacteria brake down the ammoniacal nitrogen $\left(\mathrm{NH}_{3}-\mathrm{N}\right)$ excreted by the fish into nitrites and nitrates and (4) a denitrification reactor where denitrifying bacteria processes nitrates into nitrogen gas $\left(\mathrm{N}_{2}\right)$. Clean-up water was re-used in rearing tanks and only $30 \mathrm{~m}^{3} /$ day of effluent water was directed to a municipal waste water treatment plant. The bioeconomic model was divided in 3 parts: (1) fish model, estimating individual fish growth using thermal growth coefficient (Dumas et al., 2007) and estimating individual emission of pollutants using mass-balance (Cho and Kaushik, 1990; Cowey and Cho, 1991); (2) batch model, estimating the maximum stocking density of a batch according to the two limiting factors, the density at harvest $\left(230 \mathrm{~kg} / \mathrm{m}^{3}\right)$ and the maximum treatment 
1 capacity of the bio-filter (40 kg of dissolved $\mathrm{NH}_{3}-\mathrm{N}$ per day); (3) farm model, estimating

2 annual fish production, pollutants emission, feed consumption and finally annual profit by

3 combining technical and economic parameters. Further details about the bioeconomic model

4 are given in appendix A.1. The outputs of the bioeconomic model were used to generate

5 inventory data for the LCA.

\subsection{Life cycle assessment}

\subsubsection{Goal and scope}

9 LCA is a standardized method to calculate the environmental impact of a production chain, from raw material extraction up to the product's end-of life (Guinée et al., 2002). In this study, 11 we applied LCA according to the main specifications of ILCD standards (Joint Research Center, 2010). The system was defined from cradle-to-farm-gate and included five distinct sub-systems (Fig. 1): (1) production of purchased feed, including cultivation of ingredients, processing, and transportation; (2) production of energy expended at farm level (electricity and gas); (3) production of farming facilities and equipment used; (4) fish farming, including nutrients emission from biological transformation of feed after onsite treatment of wastewater; (5) offsite treatment of effluent at a municipal wastewater treatment plant. The functional unit in which environmental impacts were expressed was ton of fish produced at farm level on a basis of one year of routine production.

\subsubsection{Life cycle inventory}

(1) Production of purchased feed - Crop-derived ingredients used in fish feed originated from

Brazil and France (e.g. soybean meal from brazil and wheat bran from France), whereas fishderived ingredients originated from the Peruvian and the Norwegian fish milling industry (e.g. 
1 composition is given in appendix A.2. Economic allocation was used to calculate the

2 environmental impacts of processes yielding multiple products. We choose economic

3 allocation because it has the advantage of stimulating the use of by-products from crops in

4 feed ingredients for livestock compare to mass allocation, which put high environmental

5 impacts to by-products with high mass value. Economic allocation is, therefore, the most used

6 method to deal with process yielding multiple outputs in livestock production systems (de

7 Vries and de Boer, 2010). The transport of feed ingredients to feed manufacture in France was by transoceanic ship and by lorry (>32t), whereas the transport of feed from France to the fish farm in Eindhoven was by lorry (>32t). Transport distances and other data required to compute the environmental impact of feed ingredients were based on the literature (Boissy et al., 2011; Pelletier et al., 2009), and presented in detail in appendices A.2 and A.3.

(2) Production of energy expended on farm - The energy consumed by the farm was considered fixed at $600 \mathrm{MWh}$ per year of electricity and $600 \mathrm{MWh}$ per year of natural gas. The electricity used by the farm was coming from the Dutch energy mix proposed by Ecoinvent v2.2 database (Swiss Centre for Life Cycle Inventories, 2010). Contribution analysis is available in appendix A.4.

(3) Production of farming facilities and equipment used - We consider the construction of a building of $5200 \mathrm{~m}^{2}$ with a life span of 30 years. The production of equipment used (i.e. pump, tanks) was calculated using data from INRA and corresponded to $11477 \mathrm{~kg}$ of material used for a building of $5200 \mathrm{~m}^{2}$ per year. The use of building and equipment was considering fixed per year at farm level. Contribution analysis is available in appendix A.5.

(4) Fish farming - The farm operation sub-system includes the use of energy, facilities and equipment as well as the emission of pollutants from biological transformation of the feed distributed to the fish. The amount of nitrogen $(\mathrm{N})$, phosphorus $(\mathrm{P})$ and chemical oxygen demand (COD) of the dissolved organic matter excreted by the fish in effluent water were calculated through the bioeconomic model based on the onsite treatment capacity of the biofilter. The effluent water was further treated in an offsite wastewater treatment plant. The 
1 sludge produced by the farm was used for agricultural purposes and was not included in the

2 analysis.

3 (5) Offsite treatment of waste water - Effluent water, highly concentrated in nutrients, coming

4 from the fish farm was disposed in a plant treating wastewater. We considered a typical

5 treatment plant running in Europe, including three treatment stages: mechanical treatment,

6 biological treatment, chemical treatment. It also included sludge digestion via fermentation.

7 Life cycle inventory data of water treatment were extracted from Ecoinvent v2.2 database

8 (Swiss Centre for Life Cycle Inventories, 2010). The final amount of nutrients emitted to the

9 environment was calculated based on the capacity of the offsite plant to treat wastewater.

Thus, $28 \%$ of the COD, $75 \%$ of the nitrogen and $52 \%$ of the phosphorus coming from the fish

11 farm were assumed to be released into water (Swiss Centre for Life Cycle Inventories, 2010).

12 Contribution analysis is available in appendix A.6.

\subsubsection{Life cycle impact assessment}

Each flow observed in the system was assigned to different impact categories relatively to its potential environmental effects. The four environmental categories investigated were: eutrophication, acidification, climate change (CML2 Baseline 2000 version 2.04)(Guinée et al., 2002) and cumulative energy demand (Frischknecht et al., 2007). These four impact categories were chosen because they represent the main environmental impacts that aquaculture contributes to (Aubin, 2013; Henriksson et al., 2012; Pelletier et al., 2007) Eutrophication is mainly the consequence of the emissions of nitrogen $(\mathrm{N})$ and phosphorus $(\mathrm{P})$ to the air, water and soil and is expressed in $\mathrm{kg} \mathrm{PO}_{4}{ }^{3-}$ equivalents. Acidification refers to negative effects of acidifying pollutants, such as $\mathrm{SO}_{2}, \mathrm{NO}_{\mathrm{x}}, \mathrm{HCL}$ and $\mathrm{NH}_{3}$, on the environment and is expressed in $\mathrm{kg} \mathrm{SO}_{2}$-equivalents. Climate change is the potential impact of gaseous emissions, such as $\mathrm{CO}_{2}$ and $\mathrm{CH}_{4}$ on the heat radiation absorption in the atmosphere. Climate change was calculated according to the GWP100 factors (potential effect 
1 at a 100-year time horizon) and expressed in $\mathrm{kg} \mathrm{CO}_{2}$-equivalents. Cumulative energy demand

2 expresses the depletion of energy resources, expressed in MJ. The characterisation factors

3 from CML2 Baseline 2000 version 2.04 were used for eutrophication, acidification and

4 climate change. The impact categories were calculated using Simapro® 7.0 software.

\subsection{Environmental values}

Similarly to the economic values proposed by Hazel (1943), environmental values (ENV) express the change in each environmental impact category as a result of one generation of selection for a given trait while keeping the other trait constant. We calculated ENV for two important traits representing rearing performances of a farm, the thermal growth coefficient (TGC) and the feed conversion ratio (FCR). Rearing performances in the reference scenario were 8.33 for TGC and 0.81 for FCR. Changes in environmental impacts were calculated as environmental impacts per ton of fish produced before genetic improvement minus environmental impacts per ton of fish produced after genetic improvement. Genetic parameters for TGC and FCR are not yet available for African catfish, therefore, as in Besson et al. (2014), we used genetic parameters of rainbow trout (Onchorhynchus mykiss) to estimate genetic improvement $\left(\Delta_{\mathrm{t}}\right)$ in both trait (Sae-Lim et al., 2012): $\Delta_{\mathrm{TGC}}=\mu_{\mathrm{TGC}} \times$ $6.8 \%$ and $\Delta_{\mathrm{FCR}}=\mu_{\mathrm{FCR}} \times 7.6 \%$. We used genetic parameters of rainbow trout as a proxy because there are not yet genetic parameters for African catfish. This proxy is in the range of what has been observed or estimated in many fish species (Gjedrem et al., 2012; Gjedrem and Thodesen, 2005). The different FCR values were obtained by varying only the weight exponent of the $\mathrm{FCR}_{\mathrm{wn}}$ formula (Appendix A.1). The model assumes genetic improvement of the traits over time. We calculated values at several hypothetical time points within that "transition" period. $\mathrm{ENV}_{\mathrm{TGC}}$ and $\mathrm{ENV}_{\mathrm{FCR}}$ were calculated for two generations of selection for each trait, which resulted in nine scenarios and nine $\mathrm{ENV}_{\mathrm{TGC}}$ and $\mathrm{ENV}_{\mathrm{FCR}}$ (Table 1). The endpoint of selection and thus transition period, is not defined. 
1 3. Results

2 3.1. Environmental impacts in the reference scenario

3 In the reference scenario $(\mathrm{TGC}=8.33$ and $\mathrm{FCR}=0.81$ ), fish production is limited to 518 tons

4 per year because emission of dissolved $\mathrm{NH}_{3}-\mathrm{N}$ by the fish at maximum standing stock reaches

5 the maximum treatment capacity of the bio-filter, $40 \mathrm{~kg} /$ day. Table 2 shows the contribution

6 of each different sub-systems to the four environmental impact categories in this scenario.

7 Production of purchased feed is by far the main contributor for acidification, climate change

8 and cumulative energy demand (respectively $57.2 \%, 72.3 \%, 68.5 \%$ ). The second major

9 contributors to these impact categories are the fixed sub-systems at farm level, i.e. production

10 of facilities and equipment used contributes to $37.6 \%$ to acidification, production of energy

11 expended contributes to $21.5 \%$ to climate change and to $23.8 \%$ to cumulative energy demand.

12 Conversely, the two main contributors to eutrophication are farm operation (68.5\%) and 13 production of feed purchased (38.9\%).

\subsection{Effects of genetic improvement in TGC and FCR}

In our previous study (Besson et al., 2014), we showed that the economic response to genetic improvement in TGC and FCR is different depending on whether the limiting factor is dissolved $\mathrm{NH}_{3}-\mathrm{N}$ or rearing density. Depending on the limiting factor, genetic improvement will impact production (i.e. annual fish production) and production efficiency (i.e. ton of fish produced per ton of feed consumed) differently (Table 3). Increasing production, while keeping the same production efficiency, dilutes environmental impacts that are fixed at farm

21 level, such as production of facilities and equipment used, over more fish produced.

22 Increasing production efficiency, while keeping the same production, decreases the amount of 23 feed required to produce one ton of fish and decreases the amount of nutrients emitted per ton of fish, which decreases environmental impacts. Consequently, the environmental response to 
1 genetic improvement in FCR and TGC after 2 generations of selection is different depending

2 on whether the limiting factor is dissolved $\mathrm{NH}_{3}-\mathrm{N}$ or rearing density (Fig. 2).

3 3.2.1. Dissolved $\mathrm{NH}_{3}-\mathrm{N}$ as limiting factor

4 Faster growing fish have higher daily feed intake (at constant FCR), which increases

5 dissolved $\mathrm{NH}_{3}-\mathrm{N}$ excreted per fish per day. When dissolved $\mathrm{NH}_{3}-\mathrm{N}$ is the limiting factor,

6 fewer fish should be stocked per batch to respect the limitations on dissolved $\mathrm{NH}_{3}-\mathrm{N}$ defined

7 by the treatment capacity of the bio-filter. This decreasing number of fish is offset by the

8 possibility to rear more batches. Consequently, improving TGC (without changing FCR)

9 when dissolved $\mathrm{NH}_{3}-\mathrm{N}$ is the limiting factor does not improve production nor production

10 efficiency (Table 3) and environmental impacts remain constant (superimposed lines on Fig.

$112)$.

12 On the other hand, improving FCR (at constant TGC) results not only in lower total feed 13 distributed per fish but also in lower dissolved $\mathrm{NH}_{3}-\mathrm{N}$ excreted per day. With lower excretion,

14 the number of fish stocked per batch can be increased until the limitation on dissolved $\mathrm{NH}_{3}-\mathrm{N}$

15 is reach again. Consequently, improving FCR when dissolved $\mathrm{NH}_{3}-\mathrm{N}$ is the limiting factor 16 improves production efficiency and production (Table 3), which decreases environmental 17 impacts per ton of fish produced (Fig. 2).

\subsubsection{Rearing density as limiting factor}

19 When rearing density is the limiting factor and the dissolved $\mathrm{NH}_{3}-\mathrm{N}$ excretion is below the 20 limit set by the bio-filter, the number of fish harvested per batch is constant. Improving FCR

21 (at constant TGC) decreases the total amount of feed distributed per fish. With fixed densities, 22 improving FCR increases production efficiency (Table 3), which decreases environmental 23 impacts per ton of fish produced (Fig. 2).

24 Improving TGC (at constant FCR) increases the number of batches reared during a year. 25 Consequently, improving TGC when rearing density is the limiting factor improves 
1 production (Table 3), which decreases environmental impacts per ton of fish produced (Fig.

2 2). The environmental response to genetic improvement in TGC, however, differs among

3 impact categories. Improving TGC in this situation decreases acidification, climate change,

4 cumulative energy demand quite significantly and eutrophication only to a very limited

5 extent. The difference can be explained by the main sub-systems contributing to the impact

6 categories.

7 Eutrophication is dependent on the production of feed purchased and on farm operation due to

8 the emission of $\mathrm{NH}_{3}-\mathrm{N}$ directly into the water (Table 2). When rearing density is the limiting

9 factor, increasing TGC increases production, which increases not only the annual

10 consumption of feed but also the emission of $\mathrm{NH}_{3}-\mathrm{N}$. Consequently, improving TGC has little

11 impact on eutrophication because the dilution of fixed environmental impacts over more fish

12 produced is almost compensated by the increase in the annual emission of nitrogen and the 13 increase in annual purchased of feed.

14 In most livestock system, $\mathrm{NH}_{3}-\mathrm{N}$ is released into the air and contributes to acidification. In

15 fish farming, however, $\mathrm{NH}_{3}-\mathrm{N}$ is released into the water and does not participate to 16 acidification. Consequently, the sub-systems contributing to acidification are the production 17 of feed purchased and the production of facilities and equipment used (Table 2). Thus, when 18 rearing density is the limiting factor, improving TGC increases production, which dilutes 19 fixed environmental effects of the production of facilities and equipment used, over more fish 20 produced.

21 Climate change and cumulative energy demand are both influenced by the production of feed 22 purchased and by the production of energy expended (Table 2). When rearing density is the 23 limiting factor, improving TGC increases production, which dilutes fixed environmental 24 impacts of the production of energy expended over more fish produced. 
3.3. Environmental values (ENV)

\section{3.3.1. Effects of changes in TGC (Table 4)}

3 When dissolved $\mathrm{NH}_{3}-\mathrm{N}$ is the limiting factor, $\mathrm{ENV}_{\mathrm{TGC}}$ are null as TGC does not alter

4 environmental impacts. When rearing density is the limiting factor, $\mathrm{ENV}_{\mathrm{TGC}}$ are positive 5 because increasing TGC increases production, which in turn dilutes fixed costs and

6 environmental impacts at farm level. $\mathrm{ENV}_{\mathrm{TGC}}$ for eutrophication is, however, close to zero

7 because, as mentioned earlier, improvement in TGC increases not only production but also

8 feed consumption and nutrients emission

9 3.3.2. Effects of changes in FCR (Table 5)

10 When dissolved $\mathrm{NH}_{3}-\mathrm{N}$ is the limiting factor, $\mathrm{ENV}_{\mathrm{FCR}}$ are positive because improving FCR 11 increases both production and production efficiency. When rearing density is the limiting 12 factor, $\mathrm{ENV}_{\mathrm{FCR}}$ of acidification, climate change and cumulative energy demand are also positive but to a lower extent because improved FCR increases production efficiency only.

\section{Discussion}

16 We combined bioeconomic modelling and life cycle assessment to assess the environmental

17 consequences of genetic improvement in thermal growth coefficient (TGC) and in feed conversion ratio (FCR), in a recirculating aquaculture system (RAS). This combined approach allows to calculate environmental values (ENV) of selected traits, which express the changes in environmental impacts due to genetic improvement of a trait. A cradle-to-farm-gate LCA

21 was carried to avoid over estimation of ENV of traits decreasing environmental impacts at

22 farm level, but increasing environmental impacts at chain level (van Middelaar et al., 2014).

23 The results showed that the ENV of FCR and TGC depend on the limiting factor, density or 24 dissolved $\mathrm{NH}_{3}-\mathrm{N}$. 
1 In case dissolved $\mathrm{NH}_{3}-\mathrm{N}$ was the limiting factor, improving TGC did not increase production

2 or production efficiency. In case density was the limiting factor, however, improving TGC

3 increased production, which diluted fixed environmental impacts over more fish produced.

4 Consequently, the environmental impacts per ton of fish produced decreased. The magnitude

5 of the environmental value of TGC is, therefore, dependent on the relative importance of

6 fixed environmental impacts. An energy mix with a greater contribution of fossil energy, for

7 example, would increase the relative importance of fixed environmental impacts of the farm,

8 which would lower the reduction of environmental impacts per ton of fish produced observed

9 when production increases. The direction of the change, however, would stay the same, and

10 increasing production would always decrease the environmental impacts per ton of fish

11 produced. The dilution of fixed environmental impacts per unit of fish produced reflects how

12 efficient capital goods, such as energy input, are used. The relevance of the capital goods

13 inclusion, therefore, is closely correlated to the target question of the study and to the type of

14 system. In RAS, the weight of capital good is high relatively to total plant production

15 capacity. In RAS, therefore, the environmental costs of capital goods are not sufficiently

16 diluted by the production level to be neglected.

17 The results obtained could be analysed also through a geographic perspective, by splitting 18 global and local environmental impacts. For instance, the emission of greenhouse gases 19 contributing to climate change is a global issue. In RAS, climate change is mainly caused by 20 capital goods thus, climate change can be diluted with higher production. Conversely, the 21 emission of nutrients participating to eutrophication has an impact at local scale on the 22 neighbourhood of the emission source. The emission of nutrients from the biological 23 transformation of the feed is variable and increases with higher production. Therefore, when 24 density is the limiting factor, improving TGC increases production and dilutes climate change 
1 at global scale but it does not affect eutrophication at local scale. The environmental values

2 can be used also to assess the impact of genetic change at global or local scale.

3 FCR, however, always decreased environmental impacts, because improving FCR improved

4 production efficiency, in case density was the limiting factor, and production efficiency plus

5 production, in case dissolved $\mathrm{NH}_{3}-\mathrm{N}$ was the limiting factor. Compared to TGC, therefore, an

6 improvement of FCR does not only dilute fixed environmental impacts, but also reduces the

7 use variable inputs such as feed per unit of fish produced. Consequently, improving FCR

8 would also have a positive effect on environmental impacts. d'Orbcastel et al. (2009)

9 investigated the impact of a RAS producing rainbow trout with different value of FCR, 1.1

10 and 0.8 . This range would correspond to $27.3 \%$ of improvement, or 3.6 generations of

11 selection in case percentage of improvement in FCR is $7.6 \%$ per generation, as in this study.

12 Scaling their results to our genetic response shows that decreasing FCR by $7.6 \%$ decreased 13 acidification by $5.8 \%$, eutrophication by $4.3 \%$, climate change by $6 \%$ and cumulative energy

14 demand by $2.4 \%$. The environmental values calculated from d'Orbcastel et al. (2009), 15 therefore, are similar to the $\mathrm{ENV}_{\mathrm{FCR}}$ calculated in our study for acidification, climate change 16 and cumulative energy demand., in case rearing density is the limiting factor, These similar 17 results are the consequence of better production efficiency observed in d'Orbcastel et al. 18 (2009) study and in our study, in case rearing density is the limiting factor. The response in eutrophication, however, is higher (18.6\%) in our study than in d'Orbcastel et al. (2009), 20 because our bioeconomic model includes a mass-balance approach to evaluate nitrogen 21 emission of the fish. In case density at harvest is the limiting factor, improving FCR not only 22 decreases feed consumption but also decreases nitrogen emission, which plays an important 23 role in eutrophication.

24 Using dynamic modelling of the relationship between genetic improvement and farm 25 management (i.e. number of fish stocked per batch), the results shows that improving FCR 
1 can lead to switch limiting factors. Then, when dissolved $\mathrm{NH}_{3}-\mathrm{N}$ becomes the new limiting

2 factor improving FCR increases also production. In our study, changes in ENV represent not

3 only the direct change in environmental impacts, due to a change in a trait, but also the

4 indirect change due to changes in number of fish and changes in farm management (van

5 Middelaar et al., 2014). It is, therefore, difficult to fully use the results from d'Orbcastel et al.

6 (2009) as a comparison basis for our results, because we considered all changes that could

7 occur in farm management when genetic improvement occurs.

8 Genetic improvement is also a tool used for economic development in fish farming. In Besson

9 et al. (2014), we calculated economic values FCR and TGC using the bioeconomic model. It

10 is, therefore, possible to compare those economic values and environmental values from our

11 simulations (Tables 4 and 5). The comparison underlines interesting synergies between

12 economic and environmental values. Both values depend on the nature of the limiting factor,

13 whether rearing density or dissolved $\mathrm{NH}_{3}-\mathrm{N}$. When $\mathrm{NH}_{3}-\mathrm{N}$ is the limiting factor, only genetic

14 improvement in FCR increases profit $\left(\mathrm{EV}_{\mathrm{FCR}}=0.13 € / \mathrm{kg}\right.$ of fish and $\mathrm{EV}_{\mathrm{TGC}}=0 € / \mathrm{kg}$ of fish)

15 and decreases environmental impacts because it increases both production and production

16 efficiency. On the contrary, when rearing density is the limiting factor both genetic

17 improvement in TGC and FCR increase profit $\left(\mathrm{EV}_{\mathrm{FCR}}=0.06 € / \mathrm{kg}\right.$ of fish and $\mathrm{EV}_{\mathrm{TGC}}=0.03$

$18 € / \mathrm{kg}$ of fish) and decrease environmental impacts because improving FCR increases

19 production efficiency and improving TGC increases production. Such synergies between

20 economic and environmental values have been observed also in dairy cow by van Middelaar

21 et al. (2014), who found that a genetic improvement of milk yield and longevity increased

22 economic return and decreased greenhouse gases emissions per unit of fat-and-protein-

23 corrected milk.

24 It is established that the quality and quantity of protein in the feed can have an impact on FCR

25 of fish (Albrektsen et al., 2006). In the present study we assumed, therefore, a fixed diet and 
1 we assumed that improvement in FCR was exclusively due to genetic improvement. Our

2 results confirm that FCR would be the major trait to include in the breeding goals for

3 increasing economic profit and decreasing environmental impacts in RAS. This can be

4 explained by the importance of the feed in farm costs but also in environmental impacts. As a

5 result, any improvement in FCR will at the same time increase farm incomes and decrease

6 environmental impacts.

7 In fish breeding FCR is a difficult trait to improve as it is difficult to measure individual feed

8 intake. FCR is expected to be correlated to TGC, however, studies diverge on this subject. In

9 rainbow trout, Kause et al. (2006) predicted that selection only for daily gain, increases daily

10 gain by $17.6 \%$ per generation and simultaneously increases feed efficiency (1/FCR) by $8.4 \%$.

11 In parallel, some other studies in salmonids did not observe any correlation between growth

12 rate and feed efficiency and showed that genetic gain in growth is due to higher feed intake,

13 while feed efficiency remains unchanged (Mambrini et al., 2004; Sanchez et al., 2001).

14 As a result, fish breeders developed breeding programs aiming mainly to improve growth rate, 15 easier to measure, assuming a positive correlation with feed conversion ratio. Our 16 results(Besson et al. 2014) and the present study show, however, that improvement in TGC 17 may result in an increase in economic profit and a decrease in environmental impacts only in 18 specific conditions (when rearing density is the limiting factor). It means that without genetic 19 correlation between growth rate and feed conversion ratio, such breeding programs aiming 20 only at increasing growth rate when $\mathrm{NH}_{3}-\mathrm{N}$ is the limiting factor would not be economically 21 and environmentally beneficial.

22 These findings can be extended to other livestock systems where animal manure is 23 responsible for high environmental impacts. In the UK, farmers located in Nitrate Vulnerable 24 Zones (NVZs), are restricted in the amount of nitrogen from livestock manure they can apply 25 on their farm (Department for Environment Food \& Rural Affairs, 2013). With such 
1 limitation, faster growing animals (with the same feed efficiency) will have a similar impact

2 as faster growing fish in RAS when dissolved $\mathrm{NH}_{3}-\mathrm{N}$ is the limiting factor. Faster growing

3 animals would increase production rate but farmers would have to keep fewer animals, which

4 will keep the environmental impacts constant.

5 The results of the study confirm the importance of precisely defining the rearing system and

6 its production limiting factors to be able to design effective breeding programs in terms of

7 environmental or economic consideration. Environmentally effective breeding program could

8 be developed by using environmental values, which would put more emphasis on the most

9 relevant traits in a specific limiting factor situation. Furthermore, the synergy between

10 economic and environmental values is a conductive factor for the development of

11 economically and environmentally efficient breeding program.

12

\section{5. Conclusion}

14 The framework applied in this study is a first step towards the future development of selective breeding programs in fish farming considering environmental objectives. We showed that there are opportunities of developing breeding objectives aiming at reducing environmental impacts while at the same time maintaining economic objectives. In other words, economic profit and environmental impacts are not antagonists. In recirculating aquaculture system, thermal growth coefficient (TGC) and feed conversion ratio (FCR) were identified as two production traits that can contribute to improve both economic and environmental

21 performances. In particular, improvement in FCR always improves environmental impacts

22 and increases economic incomes in the range of scenarios tested. On the other hand, selecting

23 for increased TGC is only relevant in specific situations. This result emphasizes the need for

24 further studies aiming at better characterising the genetic bases of feed efficiency, especially 25 any possible genetic correlation with growth trait, to implement efficient selective breeding 
1 program for improving feed efficiency. The results obtained in this study are, however,

2 characteristic to a RAS and this framework needs to be tested on other systems where

3 economic and environmental responses to selection might be different. For instance, in sea

4 cages system, waste water is directly released into the environment and fish production relies

5 on environmental conditions such as water temperature and oxygen availability. Such

6 differences could lead to different economic and environmental values of growth rate and feed

7 conversion ratio in different systems.

8

9 Acknowledgement

10 M. Besson benefited from a joint grant from the European Commission and IMARES, within

11 the framework of the Erasmus-Mundus joint doctorate "EGS-ABG". 
1

2 Albrektsen, S., Mundheim, H., Aksnes, A., 2006. Growth, feed efficiency, digestibility and

\section{References}

4 three dietary levels of vegetable protein sources. Aquaculture. 261, 626-640. nutrient distribution in Atlantic cod (Gadus morhua) fed two different fish meal qualities at Aubin, J., 2013. Life Cycle Analysis as applied to environmental choices regarding farmed or wildcaught fish, CAB Reviews. CAB International.

Aubin, J., Papatryphon, E., van der Werf, H.M.G., Chatzifotis, S., 2009. Assessment of the environmental impact of carnivorous finfish production systems using life cycle assessment. J. Clean. Prod. 17, 354-361.

Aubin, J., Papatryphon, E., van der Werf, H.M.G., Petit, J., Morvan, Y.M., 2006. Characterisation of the environmental impact of a turbot (Scophthalmus maximus) recirculating production system using Life Cycle Assessment. Aquaculture. 261, 1259-1268. Ayer, N.W., Tyedmers, P.H., 2009. Assessing alternative aquaculture technologies: life cycle assessment of salmonid culture systems in Canada. J. Clean. Prod. 17, 362-373.

Bell, M.J., Wall, E., Russell, G., Simm, G., Stott, A.W., 2011. The effect of improving cow productivity, fertility, and longevity on the global warming potential of dairy systems. J. Dairy. Sci. 94, 3662-3678.

Besson, M., Komen, H., Aubin, J., de Boer, I.J.M., Poelman, M., Quillet, E., Vancoilie, C., Vandeputte, M., van Arendonk, J.A.M., 2014. Economic values of growth and feed efficiency for fish farming in recirculating aquaculture system with density and nitrogen output limitations: a case study with African catfish (Clarias gariepinus). J. Anim. Sci. 92, 53945405.

Boissy, J., Aubin, J., Drissi, A., van der Werf, H.M.G., Bell, G.J., Kaushik, S.J., 2011. Environmental impacts of plant-based salmonid diets at feed and farm scales. Aquaculture. $321,61-70$. 
1 Buddle, B.M., Dennis, M., Attwood, G.T., Altermann, E., Janssen, P.H., Ronimus, R.S.,

2 Pinares-Patiño, C.S., Muetzel, S., Neil Wedlock, D., 2011. Strategies to reduce methane

3 emissions from farmed ruminants grazing on pasture. Vet. J. 188, 11-17.

4 Cho, C.Y., Kaushik, S. J., 1990. Nutritional energetics in fish: energy and protein utilization

5 in rainbow trout (Salmo gairdneri). World. Rev. Nutr. Diet. 61, 132-172.

6 Cowey, C.B., Cho, C.Y., 1991. Nutritional Strategies and Aquaculture Waste. Proc. 1st Int.

7 Symp. Nutr. Strategies Manage. Aquaculture Waste. Univ. Guelph, Guelph, Ontario, Canada.

8 De Vries, M., De Boer, I.J.M., 2010. Comparing environmental impacts for livestock

9 products: A review of life cycle assessments. Livest. Sci. 128, 1-11.

10 d'Orbcastel, E.R., Blancheton, J.-P., and Aubin, J., 2009. Towards environmentally

11 sustainable aquaculture: Comparison between two trout farming systems using Life Cycle

12 Assessment. Aquacult. Eng. 40, 113-119.

13 Dumas, A., France, J., Bureau, D. P., 2007. Evidence of three growth stanzas in rainbow trout 14 (Oncorhynchus mykiss) across life stages and adaptation of the thermal-unit growth 15 coefficient. Aquaculture. 267, 139-146.

16 Ecoinvent, 2010. Online: http://www.ecoinvent.ch/.

17 Folke, C., Kautsky, N., Troell, M., 1994. The Costs of Eutrophication from Salmon Farming: 18 Implications for Policy. J. Environ. Manage. 40, 173-182.

19 Frischknecht, R., Jungbluth, N., Althaus, H.J., Doka, G., Heck, T., Hellweg, S., Hischier, R., 20 Nemecek, T., Rebitzer, G., Spielmann, M., Wenet, G., 2007. Overview and Methodology. 21 Swiss Centre for Life Cycle Inventories, Dübendorf, Switzerland.

22 Gibson, J.P., 1989. Economic weights and index selection of milk production traits when 23 multiple production quotas apply. Anim. Sci. 49, 171-181. 
1 Gjedrem, T., Robinson, N., Rye, M., 2012. The importance of selective breeding in

2 aquaculture to meet future demands for animal protein: A review. Aquaculture. 350-353, 117 3129.

4 Gjedrem, T., Thodesen, J., 2005. Selection. In: Gjedrem, T. (Ed.), Selection and Breeding

5 Programs in Aquaculture. Springer, p. 364.

6 Groen, A., 1989. Economic values in cattle breeding. II. Influences of production

7 circumstances in situations with output limitations. Livest. Prod. Sci. 22, 17-30.

8 Groen, A.F., 1988. Derivation of economic values in cattle breeding: A model at farm level.

9 Agr. Syst. 27, 195-213.

10 Guinée, J.B., Gorrée, M., Heijungs, R., Huppes, G., Kleijn, R., de Koning, A., van Oers, L.,

11 Wegener Sleeswijk, A., Suh, S., de Haes, H.A.U., de Bruijn, H., van Duin, R., Huijbregts, 12 M.A.J., Lindeijer, E., Roorda, A.A.H., van der Ven, B.L., Weidema, P.P., 2002. Handbook 13 on Life Cycle Assessment, Operational Guide to the ISO Standards. Kluwer Academic 14 Publishers, Dordrecht, The Netherlands.

15 Hazel, L.N., 1943. The genetic basis for constructing selection indexes. Genetics. 28, 47616490.

17 Henriksson, P.G., Guinée, J., Kleijn, R., Snoo, G., 2012. Life cycle assessment of aquaculture 18 systems - a review of methodologies. Int. J. Life. Cycle. Assess. 17, 304-313.

Kause, A., Tobin, D., Houlihans, D.F., Martin, S.A.M., Mäntusaari, E.A., Ritola, O.,

Ruohonen, K., 2006. Feed efficiency of rainbow trout can be improved through selection:

21 Different genetic potential on alternative diets. J. Anim. Sci. 84, 807-817.

22 Mambrini, M., Médale, F., Sanchez, M.P., Recalde, B., Chevassus, B., Labbé, L., Quillet, E., 23 Boujard, T., 2004. Selection for growth in brown trout increases feed intake capacity without 24 affecting maintenance and growth requirements. J. Anim. Sci. 82, 2865-2875. 
1 Naylor, R.L., Goldburg, R.J., Primavera, H.J., Kautsky, N., Beveridge, M.C.M., Clay, J.,

2 Folke, C., Lubchenco, J., Mooney, H., Troell, M., 2000. Effect of aquaculture on world fish

3 supplies. Nature. 405, 1017-1024.

4 Papatryphon, E., Petit, J., Kaushik, S.J., van der Werf, H.M.G., 2004. Environmental Impact

5 Assessment of Salmonid Feeds Using Life Cycle Assessment (LCA). Ambio. 33, 316-323.

6 Pelletier, N., Tyedmers, P., 2007. Feeding farmed salmon: Is organic better? Aquaculture. $7 \quad 272,399-416$.

8 Pelletier, N.L., Ayer, N.W., Tyedmers, P.H., Kruse, S.A., Flysjo, A., Robillard, G., Ziegler,

9 F., Scholz, A.J., Sonesson, U., 2007. Impact categories for life cycle assessment research of

10 seafood production systems: Review and prospectus. Int. J. Life Cycle Assess. 12, 414-421.

11 Pelletier, N., Tyedmers, P., Sonesson, U., Scholz, A., Ziegler, F., Flysjo, A., Kruse, S.,

12 Cancino, B., Silverman, H., 2009. Not All Salmon Are Created Equal: Life Cycle Assessment

13 (LCA) of Global Salmon Farming Systems. Environ. Sci. Technol. 43, 8730-8736.

14 Ponzoni, R.W., Nguyen, N.H., Khaw, H.L., 2007. Investment appraisal of genetic 15 improvement programs in Nile tilapia (Oreochromis niloticus). Aquaculture. 269, 187-199.

16 Pré Consultants, 2010. SimaPro 7. Database Manual. Methods library. The Netherlands.

17 R Development Core Team, 2008. R: A language and environment for statistical computing.

18 R Foundation for Statistical Computing, Vienna, Austria.

19 Read, P., Fernandes, T., 2003. Management of environmental impacts of marine aquaculture 20 in Europe. Aquaculture. 226, 139-163.

21 Sae-Lim, P., Komen, H., Kause, A., van Arendonk, J.A.M., Barfoot, A.J., Martin, K.E., 22 Parsons J.E., 2012. Defining desired genetic gains for rainbow trout breeding objective using 23 analytic hierarchy process. J. Anim. Sci. 90. 1766-1776. 
1 Sanchez, M.-P., Chevassus, B., Labbé, L., Quillet, E., Mambrini, M., 2001. Selection for

2 growth of brown trout (Salmo trutta) affects feed intake but not feed efficiency. Aquat.

3 Living. Resour. 14, 41-48.

4 Van Middelaar, C.E., Berentsen, P.B.M., Dijkstra, J., van Arendonk, J.A.M., de Boer, I.J.M.,

5 2014. Methods to determine the relative value of genetic traits in dairy cows to reduce

6 greenhouse gas emissions along the chain. J. Dairy. Sci. 97, 5191-5205.

7 Wall, E., Simm, G., Moran, D., 2010. Developing breeding schemes to assist mitigation of 8 greenhouse gas emissions. Animal. 4, 366-376. 


\section{$1 \quad$ Fig. 1}

2 Diagram of the system studied including emission of nitrogen $(\mathrm{N})$, phosphorus $(\mathrm{P})$ and

3 dissolved organic matter (DOM) from biological transformation of the feed by the fish.

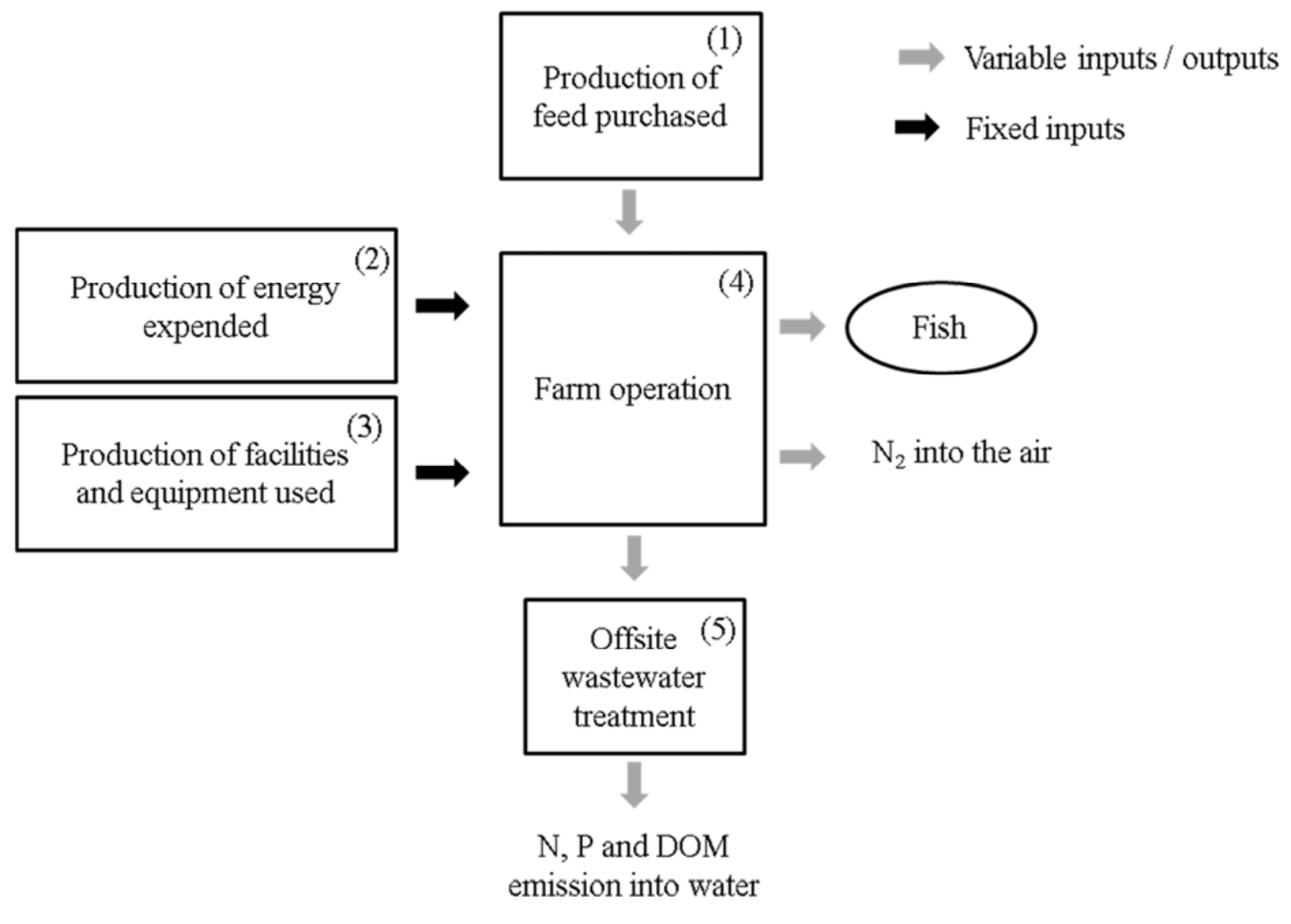




\section{Table 1}

2 Thermal growth coefficient (TGC) and feed conversion ratio (FCR) of the nine scenarios

3 tested according to two generations of selection (G1 and G2) from the reference scenario 4 (RS).

\begin{tabular}{ccccc} 
& & \multicolumn{3}{c}{ Feed conversion ratio, FCR (in kg/kg) } \\
\cline { 3 - 5 } & & $\mathrm{RS}=0.81$ & $\mathrm{G} 1=0.75$ & $\mathrm{G} 2=0.69$ \\
\hline Thermal growth & $\mathrm{RS}=8.33$ & $\times$ & $\times$ & $\times$ \\
coefficient, & $\mathrm{G} 1=8.9$ & $\times$ & $\times$ & $\times$ \\
TGC & $\mathrm{G} 2=9.5$ & $\times$ & $\times$ & $\times$ \\
\hline
\end{tabular}

5 
$1 \quad$ Table 2

2 Percentage of contribution of the different sub-systems to the four impact categories in the

3 reference scenario where $\mathrm{TGC}=8.33$ and $\mathrm{FCR}=0.81$.

\begin{tabular}{lcccc} 
& $\begin{array}{c}\text { Acidification, } \mathrm{kg} \\
\mathrm{SO}_{2} \text {-eq }\end{array}$ & $\begin{array}{c}\text { Eutrophication, } \\
\mathrm{kg} \mathrm{PO}_{4}-\mathrm{eq}\end{array}$ & $\begin{array}{c}\text { Climate change, } \\
\mathrm{kg} \mathrm{CO}_{2}-\mathrm{eq}\end{array}$ & $\begin{array}{c}\text { Cumulative } \\
\text { energy demand, } \\
\mathrm{MJ}\end{array}$ \\
\hline $\begin{array}{l}\text { Production of } \\
\text { feed purchased }\end{array}$ & $57.3 \%$ & $38.9 \%$ & $72.3 \%$ & $68.5 \%$ \\
$\begin{array}{l}\text { Production of } \\
\text { energy expended } \\
\text { on farm }\end{array}$ & $4.7 \%$ & $3.6 \%$ & $21.5 \%$ & $23.8 \%$ \\
$\begin{array}{l}\text { Production of } \\
\text { facilities and } \\
\text { equipment used }\end{array}$ & $37.7 \%$ & $0.5 \%$ & $5.4 \%$ & $7 \%$ \\
$\begin{array}{l}\text { Farm operation } \\
\text { Offsite waste }\end{array}$ & $0 \%$ & & & $0 \%$ \\
water treatment & $0.3 \%$ & $56.8 \%$ & $0 \%$ & $0.7 \%$ \\
\hline $\begin{array}{l}\text { Total \% } \\
\text { Total quantity }\end{array}$ & $100 \%$ & $0.2 \%$ & $0.8 \%$ & $100 \%$ \\
\hline
\end{tabular}

4

5 Table 3

6 Summary of the impact of genetic improvement in TGC and FCR on technical performance

7 of a recirculating aquaculture system (Besson et al., 2014).

Limiting factor

Dissolved $\mathrm{NH}_{3}-\mathrm{N}$

Density at harvest
Improved TGC

No effect
Improved FCR

Higher production

Higher production efficiency 
$1 \quad$ Fig. 2

2 Environmental impacts calculated per ton of fish for four impact categories as a function of

3 improving FCR at a given value for TGC. In graph (a), the arrows illustrate the point where

4 the limiting factor switches from dissolved $\mathrm{NH}_{3}-\mathrm{N}(\mathrm{N})$ to rearing density (D).
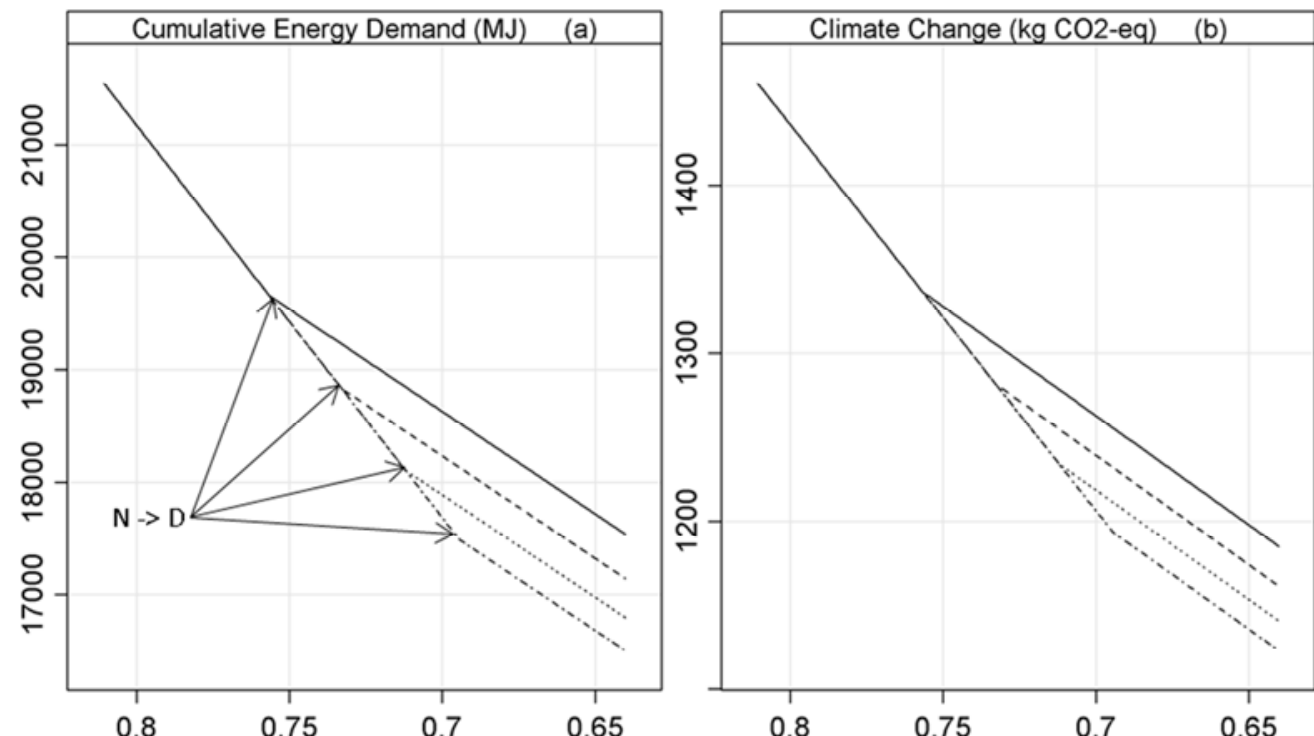

TGC
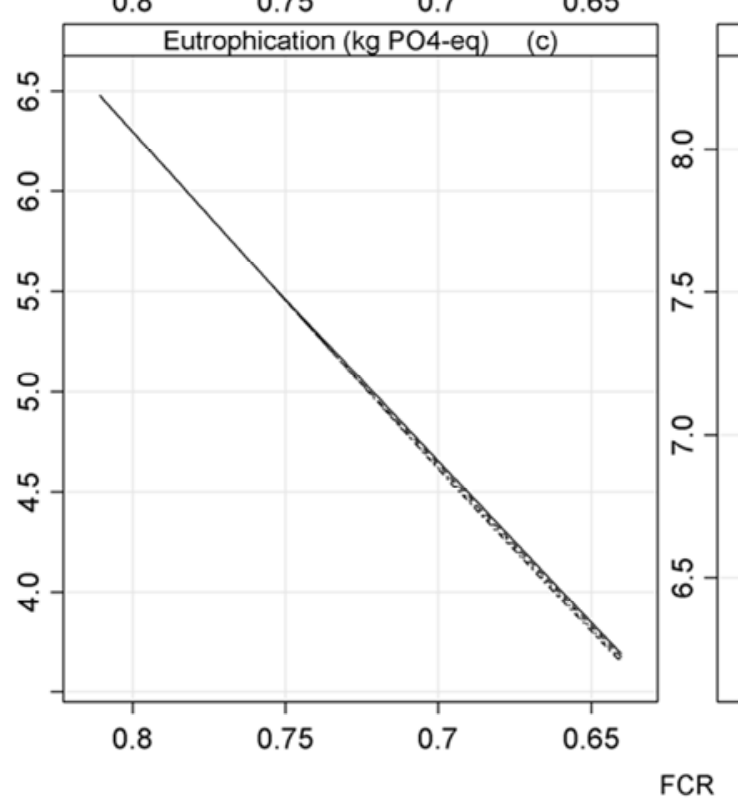

0.8
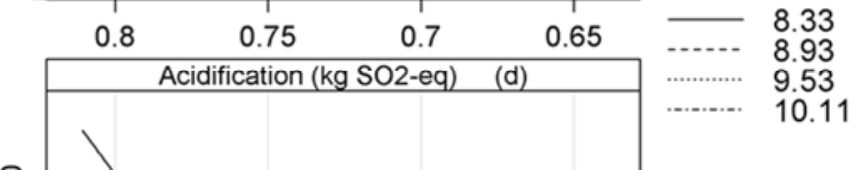

5

FCR

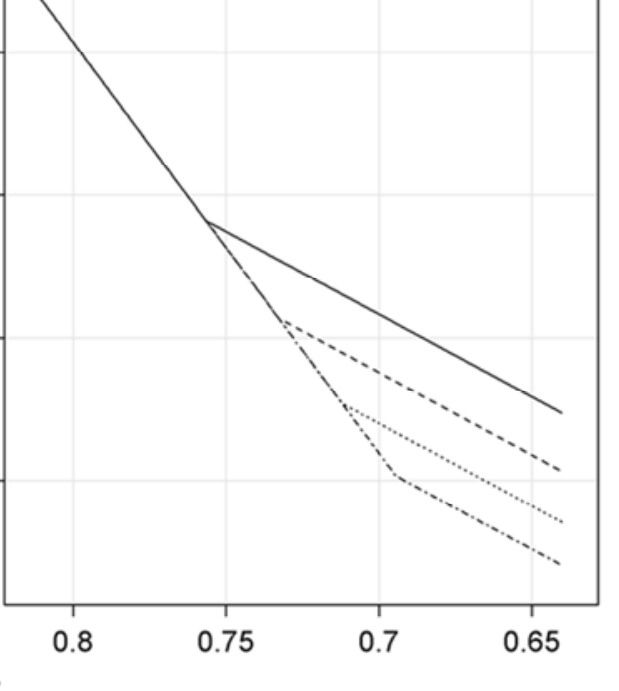

11 


\section{Table 4}

2 Economic and environmental values of four impact categories of thermal growth coefficient

3 TGC ( $\mathrm{EV}_{\mathrm{TGC}}$ and $\left.\mathrm{ENV}_{\mathrm{TGC}}\right)$ calculated in nine combinations of $\mathrm{TGC}$ and feed conversion ratio

4 FCR. For each case, the limiting factor before genetic improvement and after genetic

5 improvement is specified, $\mathrm{D}=$ rearing density and $\mathrm{N}=\mathrm{NH}_{3}-\mathrm{N}$.

\begin{tabular}{|c|c|c|c|c|c|c|c|}
\hline \multirow[b]{2}{*}{ TGC } & \multirow[b]{2}{*}{ FCR } & \multirow[b]{2}{*}{$\begin{array}{l}\text { Limiting } \\
\text { factors }\end{array}$} & \multicolumn{4}{|c|}{$\mathrm{ENV}_{\mathrm{TGC}}(\% / \mathrm{t}$ of fish $)$} & \multirow[b]{2}{*}{$\begin{array}{c}\mathrm{EV}_{\mathrm{TGC}} \\
(€ / \mathrm{kg} \text { of } \\
\text { fish) }\end{array}$} \\
\hline & & & $\begin{array}{c}\text { Acidification, } \\
\mathrm{kg} \mathrm{SO}_{2} \text {-eq }\end{array}$ & $\begin{array}{c}\text { Eutrophication } \\
, \mathrm{kg} \mathrm{PO}_{4} \text {-eq }\end{array}$ & $\begin{array}{l}\text { Climate } \\
\text { change, } \\
\mathrm{kg} \mathrm{CO}_{2^{-}} \\
\text {eq }\end{array}$ & $\begin{array}{c}\text { Cumulative } \\
\text { energy } \\
\text { demand, MJ }\end{array}$ & \\
\hline 8.33 & 0.81 & $\mathrm{~N}->\mathrm{N}$ & 0 & 0 & 0 & 0 & 0 \\
\hline 8.33 & 0.75 & $\mathrm{D} \rightarrow \mathrm{N}$ & 0.8 & 0.1 & 0.5 & 0.6 & 0.01 \\
\hline 8.33 & 0.69 & $\mathrm{D}->\mathrm{D}$ & 2.9 & 0.4 & 1.9 & 2.0 & 0.03 \\
\hline 8.9 & 0.81 & $\mathrm{~N} \rightarrow \mathrm{N}$ & 0 & 0 & 0 & 0 & 0 \\
\hline 8.9 & 0.75 & $\mathrm{~N} \rightarrow \mathrm{N}$ & 0 & 0 & 0 & 0 & 0 \\
\hline 8.9 & 0.69 & $\mathrm{D}->\mathrm{D}$ & 2.6 & 0.3 & 1.7 & 1.8 & 0.03 \\
\hline 9.5 & 0.81 & $\mathrm{~N} \rightarrow \mathrm{N}$ & 0 & 0 & 0 & 0 & 0 \\
\hline 9.5 & 0.75 & $\mathrm{~N} \rightarrow \mathrm{N}$ & 0 & 0 & 0 & 0 & 0 \\
\hline 9.5 & 0.69 & $\mathrm{D}->\mathrm{D}$ & 2.3 & 0.3 & 1.5 & 1.6 & 0.03 \\
\hline
\end{tabular}

6 
1 Table 5

2 Economic and environmental values of four impact categories of feed conversion ratio FCR

$3 \quad\left(\mathrm{EV}_{\mathrm{FCR}}\right.$ and $\left.\mathrm{ENV}_{\mathrm{FCR}}\right)$ calculated in nine combinations of thermal growth coefficient $\mathrm{TGC}$ and

4 FCR. For each case, the limiting factor before genetic improvement and after genetic

5 improvement is specified, $\mathrm{D}=$ rearing density and $\mathrm{N}=\mathrm{NH}_{3}-\mathrm{N}$.

\begin{tabular}{|c|c|c|c|c|c|c|c|}
\hline \multirow[b]{2}{*}{ TGC } & \multirow[b]{2}{*}{ FCR } & \multirow[b]{2}{*}{$\begin{array}{l}\text { Limiting } \\
\text { factors }\end{array}$} & \multicolumn{4}{|c|}{$\mathrm{ENV}_{\mathrm{FCR}}(\% / \mathrm{t}$ of fish $)$} & \multirow[b]{2}{*}{$\begin{array}{c}\mathrm{EV}_{\mathrm{FCR}} \\
(€ / \mathrm{kg} \text { of } \\
\text { fish) }\end{array}$} \\
\hline & & & $\begin{array}{c}\text { Acidification, } \\
\mathrm{kg} \mathrm{SO}_{2} \text {-eq }\end{array}$ & $\begin{array}{l}\text { Eutrophication } \\
\text {, } \mathrm{kg} \mathrm{PO}_{4} \text {-eq }\end{array}$ & $\begin{array}{l}\text { Climate } \\
\text { change, } \\
\mathrm{kg} \mathrm{CO}_{2^{-}} \\
\text {eq }\end{array}$ & $\begin{array}{c}\text { Cumulative } \\
\text { energy } \\
\text { demand, MJ }\end{array}$ & \\
\hline 8.33 & 0.81 & $\mathrm{~N}->\mathrm{D}$ & 10 & 15.9 & 9.2 & 9.3 & 0.13 \\
\hline 8.33 & 0.75 & $\mathrm{D}->\mathrm{D}$ & 4.5 & 16.8 & 5.6 & 5.4 & 0.06 \\
\hline 8.33 & 0.69 & $\mathrm{D}->\mathrm{D}$ & 4.3 & 18.6 & 5.4 & 5.3 & 0.06 \\
\hline 8.9 & 0.81 & $\mathrm{~N} \rightarrow \mathrm{N}$ & 10.8 & 15.9 & 9.7 & 9.8 & 0.14 \\
\hline 8.9 & 0.75 & $\mathrm{~N} \rightarrow \mathrm{D}$ & 6.4 & 17.0 & 6.9 & 6.8 & 0.08 \\
\hline 8.9 & 0.69 & D -> D & 4.4 & 18.7 & 5.5 & 5.4 & 0.06 \\
\hline 9.5 & 0.81 & $\mathrm{~N} \rightarrow \mathrm{N}$ & 10.8 & 15.9 & 9.7 & 9.8 & 0.14 \\
\hline 9.5 & 0.75 & $\mathrm{~N} \rightarrow \mathrm{D}$ & 8.9 & 17.3 & 8.4 & 8.5 & 0.12 \\
\hline 9.5 & 0.69 & $D->D$ & 4.6 & 18.8 & 5.6 & 5.5 & 0.06 \\
\hline
\end{tabular}

$$
6
$$




\section{Appendices}

\section{Table A.1}

3 Calculations and parameters involved in the bioeconomic model (Besson et al., 2014).

\begin{tabular}{|c|c|}
\hline Parameters & Formulas \\
\hline \multicolumn{2}{|l|}{ Fish model } \\
\hline \multicolumn{2}{|l|}{ Thermal growth coefficient (TGC) } \\
\hline$-\quad 1-b=$ weight exponent $=0.475$ & \\
\hline - $\quad T($ temperature $)=27^{\circ} \mathrm{C}$ & \\
\hline$-\quad W_{H}($ harvest weight $)=13 \mathrm{~g}$ & $\mathrm{TGC}=\frac{\mathrm{W}_{\mathrm{H}}^{1-\mathrm{D}}}{\Gamma}$ \\
\hline - $\quad W_{I}($ initial weight $)=1300 \mathrm{~g}$ & \\
\hline - $\quad n$ is the length of growing period & \\
\hline until harvest weight & \\
\hline Fish weight $\left(\mathrm{W}_{\mathrm{n}}\right)$ in $\mathrm{kg}$ & $\mathrm{W}_{n}=\left[\mathrm{W}_{\mathrm{I}}^{0.475}+\left(\mathrm{TGC} \times \sum_{\mathrm{i}=1}^{\mathrm{n}} \mathrm{T}\right)\right]^{1 / 0.475}$ \\
\hline Daily weight gain $\left(\mathrm{DWG}_{\mathrm{n}}\right)$ in $\mathrm{g}$ & $\mathrm{DWG}_{\mathrm{n}}=\mathrm{W}_{\mathrm{n}}-\mathrm{W}_{\mathrm{n}-1}$ \\
\hline Feed conversion ratio $\left(\mathrm{FCR}_{\mathrm{Wn}_{\mathrm{n}}}\right)$ in $\mathrm{g} / \mathrm{g}$ & $\mathrm{FCR}_{W n}=0.37 \times \mathrm{W}_{\mathrm{n}}^{0.112}$ \\
\hline Daily feed intake $\left(\mathrm{DFI}_{\mathrm{n}}\right)$ in $\mathrm{g}$ & $\mathrm{DFI}_{\mathrm{n}}=\mathrm{DWG}_{\mathrm{n}} \times \mathrm{FCR}_{\mathrm{Wn}}$ \\
\hline
\end{tabular}

\section{Fish waste emission}

Daily dissolved N (N_dissolved $\mathbf{n}$ ) in $\mathrm{g}$

Daily emission of $\mathrm{N}$ in effluent water $\left(\mathbf{N}_{-}\right.$eff $\left.\mathbf{n}_{\mathbf{n}}\right)$ in $\mathrm{g}$

Daily COD of effluent water (COD_eff $n$ )

- $\quad$ protein $=\%$ of protein in the feed

- $\quad$ crude_fat $=\%$ crude fat in the feed

- $\operatorname{carbs}=\%$ of carbohydrates in the feed

Daily emission of $\mathrm{P}$ in effluent water (P_eff $\left.{ }_{\mathrm{n}}\right)$
$\mathrm{N}_{-}$dissolved $_{\mathrm{n}}=\mathrm{DWG}_{\mathrm{n}}\left(\left(65.988 \times \mathrm{FCR}_{\mathrm{Wn}}\right)\right.$ $-25)$

$\mathrm{N} \_$eff $_{\mathrm{n}}=0.6732 \times \mathrm{FCR}_{\mathrm{Wn}} \times \mathrm{DWG}_{\mathrm{n}}$ COD_eff $=($ protein $\times 0.11$ + crude_fat $\times 0.24$ + carbs $\times 0.33) \times \mathrm{DFI}_{\mathrm{n}}$

$$
\text { P_eff }{ }_{\mathrm{n}}=00876 \mathrm{DFI}_{\mathrm{n}}-004 \mathrm{DWG}_{\mathrm{n}}
$$

\section{Batch model}




\begin{tabular}{|c|c|}
\hline Number of fish of $13 \mathrm{~g}$ stocked per batch & maximum NH3_N load \\
\hline$\left(\mathbf{N b}_{-} \mathbf{f i s h}_{13}\right)$ & $\sum_{\mathrm{i}=1}^{\mathrm{j}}\left(\mathrm{N}_{\text {dissolved }_{M S S}(\mathrm{j})}\right) \times\left(1-\mathrm{M}_{\mathrm{Wn}(\mathrm{j})}\right)$ \\
\hline $\begin{array}{l}\text { - Maximum } \mathrm{NH}_{3}-\mathrm{N} \text { load }=40 \\
\mathrm{~kg} / \text { day } \\
-\quad j=1 \text { to } 14 \text { (number of batch } \\
\text { reared simultaneously) }\end{array}$ & \\
\hline Cumulative mortality $\left(\mathbf{M}_{\mathbf{W n}}\right)$ in \% & $\mathrm{M}_{\mathrm{Wn}}=0001 \times \mathrm{W}_{\mathrm{n}}+0113$ \\
\hline Farm model & \\
\hline Growth period in days & $\mathrm{Nb}_{\text {days }}=\frac{\left(W_{H}^{0.475}-W_{I}^{0.475}\right) \times \mathrm{T}}{\mathrm{TGC}}=\frac{597.30}{\mathrm{TGC}}$ \\
\hline Number of batch per year & $\begin{aligned} \text { Nb_batch }= & \frac{365 \times 14}{\text { Nb_days }}=\frac{5510}{\text { Nb_days }} \\
& =9.22 \times \mathrm{TGC}\end{aligned}$ \\
\hline Economic FCR & $\mathrm{FCR}=\frac{\text { feed distributed per year }}{\text { fish production per year }}$ \\
\hline
\end{tabular}


1 Table A.2

2 Chemical composition and components of the feed of the catfish feed (Besson et al., 2014).

\begin{tabular}{lc}
\hline Chemical composition & $\%$ \\
\hline Protein & 45 \\
Crude fat & 12.5 \\
Crude ash & 9 \\
Other Carbohydrates & 22.5 \\
Phosphorus & 1.1 \\
\hline Components & $\%$ \\
\hline Fish meal, Peru & 43 \\
Fish oil, Peru & 3.4 \\
Fish meal from fish trimmings, Norway & 10.7 \\
Fish oil from fish trimmings, Norway & 0.8 \\
Soybean meal, Brazil & 9 \\
Wheat starch, France & 23.4 \\
Wheat bran, France & 8.8 \\
\hline
\end{tabular}

3 
1 Table A.3

2 Contribution analysis of $1 \mathrm{t}$ of standard African catfish feed.

\begin{tabular}{|c|c|c|c|c|}
\hline Ingredients & $\begin{array}{l}\text { Acidification, } \\
\mathrm{kg} \mathrm{SO}_{2} \text {-eq }\end{array}$ & $\begin{array}{c}\text { Eutrophication, } \\
\qquad \mathrm{kg} \mathrm{PO}_{4} \text {-eq }\end{array}$ & $\begin{array}{l}\text { Climate change, } \\
\mathrm{kg} \mathrm{CO}_{2}-\mathrm{eq}\end{array}$ & $\begin{array}{c}\text { Cumulative } \\
\text { energy demand, } \\
\text { MJ }\end{array}$ \\
\hline Fish meal & $32.6 \%$ & $24.1 \%$ & $44.2 \%$ & $41 \%$ \\
\hline Fish oil & $2 \%$ & $1.5 \%$ & $2.7 \%$ & $2.5 \%$ \\
\hline $\begin{array}{l}\text { Fish meal from fish } \\
\text { trimmings }\end{array}$ & $4.9 \%$ & $5.9 \%$ & $9.8 \%$ & $11.7 \%$ \\
\hline $\begin{array}{l}\text { Fish oil from fish } \\
\text { trimmings }\end{array}$ & $0.3 \%$ & $0.3 \%$ & $0.6 \%$ & $0.7 \%$ \\
\hline Soybean meal & $5.6 \%$ & $16.4 \%$ & $9 \%$ & $3.9 \%$ \\
\hline Wheat starch & $20.7 \%$ & $38 \%$ & $17 \%$ & $18.9 \%$ \\
\hline Wheat bran & $0.8 \%$ & $5.7 \%$ & $1.2 \%$ & $0.9 \%$ \\
\hline \multicolumn{5}{|l|}{ Other } \\
\hline $\begin{array}{l}\text { Feed processing, } \\
\text { packaging and } \\
\text { transportation }\end{array}$ & $33 \%$ & $\%$ & $15.5 \%$ & $20.4 \%$ \\
\hline Total \% & $100 \%$ & $100 \%$ & $100 \%$ & $100 \%$ \\
\hline Total quantity & 5.8 & 3.1 & 1300.2 & 18205.7 \\
\hline
\end{tabular}


1 Table A.4

2 Contribution analysis of energy carriers to acidification, eutrophication, climate change and

3 cumulative energy demand, calculated for $1000 \mathrm{kWh}$ of energy expended.

\begin{tabular}{lcccc}
\hline & $\begin{array}{c}\text { Acidification, } \\
\mathrm{kg} \mathrm{SO}_{2} \text {-eq }\end{array}$ & $\begin{array}{c}\text { Eutrophication, } \\
\mathrm{kg} \mathrm{PO}_{4} \text {-eq }\end{array}$ & $\begin{array}{c}\text { Climate change, } \\
\mathrm{kg} \mathrm{CO}_{2} \text {-eq }\end{array}$ & $\begin{array}{c}\text { Cumulative } \\
\text { energy demand, } \\
\mathrm{MJ}\end{array}$ \\
\hline $\begin{array}{l}\text { Electricity mix } \\
\text { production }\end{array}$ & $79.8 \%$ & $93 \%$ & $71.4 \%$ & $70.2 \%$ \\
$\begin{array}{l}\text { Natural gas } \\
\text { production }\end{array}$ & $20.2 \%$ & $7 \%$ & $28.6 \%$ & $29.8 \%$ \\
\hline $\begin{array}{l}\text { Total \% } \\
\text { Total quantity }\end{array}$ & $100 \%$ & $100 \%$ & $100 \%$ & $100 \%$ \\
\hline
\end{tabular}

4

5 Table A.5

6 Environmental impacts of the construction of $1 \mathrm{~m}^{2} \mathrm{y}$ of facilities, of the production $1 \mathrm{~kg}$ of

7 material, and of the treatment of $1 \mathrm{~m}^{3}$ of waste water at wastewater treatment plant.

\begin{tabular}{|c|c|c|c|c|}
\hline & $\begin{array}{l}\text { Acidification, } \\
\mathrm{kg} \mathrm{SO}_{2} \text {-eq }\end{array}$ & $\begin{array}{l}\text { Eutrophication, } \\
\qquad \mathrm{kg} \mathrm{PO}_{4} \text {-eq }\end{array}$ & $\begin{array}{l}\text { Climate change, } \\
\mathrm{kg} \mathrm{CO}_{2}-\mathrm{eq}\end{array}$ & $\begin{array}{c}\text { Cumulative } \\
\text { energy demand, } \\
\text { MJ }\end{array}$ \\
\hline $\begin{array}{l}\text { Construction of } \\
1000 \mathrm{~m}^{2} \mathrm{y} \text { of } \\
\text { facilities }\end{array}$ & 83.4 & 1.0 & 2197.8 & 43500.7 \\
\hline $\begin{array}{l}\text { Production of } 1 \text { ton } \\
\text { of equipment }\end{array}$ & 101.5 & 1.2 & 2605.1 & 48237.4 \\
\hline $\begin{array}{l}\text { Treatment of } 1 \mathrm{~m}^{3} \text { of } \\
\text { waste water }\end{array}$ & 1.1 & 0.6 & 486.7 & 5957.1 \\
\hline
\end{tabular}


1 Table A.6

2 Environmental impacts of the emission to water of one ton of nitrogen $(\mathrm{N})$, phosphorus $(\mathrm{P})$

3 and chemical oxygen demand (COD).

\begin{tabular}{lcccc}
\hline $\begin{array}{c}\text { Acidification, } \\
\text { kg SO2-eq }\end{array}$ & $\begin{array}{c}\text { Eutrophication, } \\
\text { kg PO4-eq }\end{array}$ & $\begin{array}{c}\text { Climate change, } \\
\text { kg CO2-eq }\end{array}$ & $\begin{array}{c}\text { Cumulative } \\
\text { energy demand, } \\
\text { MJ }\end{array}$ \\
\hline 1 ton of $\mathrm{N}$ & 0 & 0.42 & 0 & 0 \\
1 ton of P & 0 & 3.06 & 0 & 0 \\
1 ton of COD & 0 & 02 & 0 & 0 \\
\hline
\end{tabular}

4 


\section{Supplementary data}

\section{Table S.1}

3 Results of acidification for the 5 different sub-systems in each scenario tested.

\begin{tabular}{|c|c|c|c|c|c|c|c|}
\hline \multirow[b]{2}{*}{ TGC } & \multirow[b]{2}{*}{ FCR } & \multicolumn{6}{|c|}{ Acidification, $\mathrm{kg} \mathrm{SO}_{2}$-eq } \\
\hline & & $\begin{array}{l}\text { Production } \\
\text { of feed } \\
\text { purchased }\end{array}$ & $\begin{array}{c}\text { Production of } \\
\text { energy expended } \\
\text { on farm }\end{array}$ & $\begin{array}{l}\text { Production of } \\
\text { facilities and } \\
\text { equipment used }\end{array}$ & $\begin{array}{c}\text { Farm } \\
\text { operation }\end{array}$ & $\begin{array}{c}\text { Offsite } \\
\text { waste water } \\
\text { treatment }\end{array}$ & Total \\
\hline 8.33 & 0.81 & 3.7 & 0.3 & 2.7 & 0 & 0 & 6.7 \\
\hline 8.33 & 0.75 & 4.0 & 0.3 & 2.7 & 0 & 0 & 7.0 \\
\hline 8.33 & 0.69 & 4.3 & 0.3 & 2.7 & 0 & 0 & 7.4 \\
\hline 8.33 & 0.64 & 4.7 & 0.4 & 3.1 & 0 & 0 & 8.2 \\
\hline 8.9 & 0.81 & 3.7 & 0.3 & 2.5 & 0 & 0 & 6.5 \\
\hline 8.9 & 0.75 & 4.0 & 0.3 & 2.5 & 0 & 0 & 6.8 \\
\hline 8.9 & 0.69 & 4.3 & 0.3 & 2.6 & 0 & 0 & 7.3 \\
\hline 8.9 & 0.64 & 4.7 & 0.4 & 3.1 & 0 & 0 & 8.2 \\
\hline 9.5 & 0.81 & 3.7 & 0.3 & 2.3 & 0 & 0 & 6.4 \\
\hline 9.5 & 0.75 & 4.0 & 0.3 & 2.3 & 0 & 0 & 6.7 \\
\hline 9.5 & 0.69 & 4.3 & 0.3 & 2.6 & 0 & 0 & 7.3 \\
\hline 9.5 & 0.64 & 4.7 & 0.4 & 3.1 & 0 & 0 & 8.2 \\
\hline 10.11 & 0.81 & 3.7 & 0.3 & 2.2 & 0 & 0 & 6.2 \\
\hline 10.11 & 0.75 & 4.0 & 0.3 & 2.2 & 0 & 0 & 6.5 \\
\hline 10.11 & 0.69 & 4.3 & 0.3 & 2.6 & 0 & 0 & 7.3 \\
\hline 10.11 & 0.64 & 4.7 & 0.4 & 3.1 & 0 & 0 & 8.2 \\
\hline
\end{tabular}


$1 \quad$ Table S.2

2 Results of eutrophication for the 5 different sub-systems in each scenario tested.

\begin{tabular}{|c|c|c|c|c|c|c|c|}
\hline \multirow[b]{2}{*}{ TGC } & \multirow[b]{2}{*}{ FCR } & \multicolumn{6}{|c|}{ Eutrophication, kg PO4-eq } \\
\hline & & $\begin{array}{l}\text { Production } \\
\text { of feed } \\
\text { purchased }\end{array}$ & $\begin{array}{c}\text { Production of } \\
\text { energy expended } \\
\text { on farm }\end{array}$ & $\begin{array}{l}\text { Production of } \\
\text { facilities and } \\
\text { equipment used }\end{array}$ & $\begin{array}{c}\text { Farm } \\
\text { operation }\end{array}$ & $\begin{array}{c}\text { Offsite } \\
\text { waste water } \\
\text { treatment }\end{array}$ & Total \\
\hline 8.33 & 0.81 & 2.0 & 0.2 & 0 & 1.5 & 0 & 3.7 \\
\hline 8.33 & 0.75 & 2.2 & 0.2 & 0 & 2.1 & 0 & 4.5 \\
\hline 8.33 & 0.69 & 2.3 & 0.2 & 0 & 2.9 & 0 & 5.5 \\
\hline 8.33 & 0.64 & 2.5 & 0.2 & 0 & 3.7 & 0 & 6.5 \\
\hline 8.9 & 0.81 & 2.0 & 0.2 & 0 & 1.5 & 0 & 3.7 \\
\hline 8.9 & 0.75 & 2.2 & 0.2 & 0 & 2.1 & 0 & 4.5 \\
\hline 8.9 & 0.69 & 2.3 & 0.2 & 0 & 2.9 & 0 & 5.4 \\
\hline 8.9 & 0.64 & 2.5 & 0.2 & 0 & 3.7 & 0 & 6.5 \\
\hline 9.5 & 0.81 & 2.0 & 0.2 & 0 & 1.5 & 0 & 3.7 \\
\hline 9.5 & 0.75 & 2.2 & 0.2 & 0 & 2.1 & 0 & 4.5 \\
\hline 9.5 & 0.69 & 2.3 & 0.2 & 0 & 2.9 & 0 & 5.4 \\
\hline 9.5 & 0.64 & 2.5 & 0.2 & 0 & 3.7 & 0 & 6.5 \\
\hline 10.11 & 0.81 & 2.0 & 0.2 & 0 & 1.5 & 0 & 3.6 \\
\hline 10.11 & 0.75 & 2.2 & 0.2 & 0 & 2.1 & 0 & 4.5 \\
\hline 10.11 & 0.69 & 2.3 & 0.2 & 0 & 2.9 & 0 & 5.4 \\
\hline 10.11 & 0.64 & 2.5 & 0.2 & 0 & 3.7 & 0 & 6.5 \\
\hline
\end{tabular}


$1 \quad$ Table S.3

2 Results of climate change for the 5 different sub-systems in each scenario tested.

\begin{tabular}{|c|c|c|c|c|c|c|c|}
\hline \multirow[b]{2}{*}{ TGC } & \multirow[b]{2}{*}{ FCR } & \multicolumn{6}{|c|}{ Climate change, $\mathrm{kg} \mathrm{CO} 2-\mathrm{eq}$} \\
\hline & & $\begin{array}{l}\text { Production } \\
\text { of feed } \\
\text { purchased }\end{array}$ & $\begin{array}{c}\text { Production of } \\
\text { energy expended } \\
\text { on farm } \\
\end{array}$ & $\begin{array}{l}\text { Production of } \\
\text { facilities and } \\
\text { equipment used }\end{array}$ & $\begin{array}{c}\text { Farm } \\
\text { operation }\end{array}$ & $\begin{array}{c}\text { Offsite } \\
\text { waste water } \\
\text { treatment }\end{array}$ & Total \\
\hline 8.33 & 0.81 & 832.4 & 273.0 & 69.2 & 0.0 & 10.4 & 1185.1 \\
\hline 8.33 & 0.75 & 900.6 & 273.0 & 69.2 & 0.0 & 10.4 & 1253.2 \\
\hline 8.33 & 0.69 & 974.4 & 273.0 & 69.2 & 0.0 & 10.4 & 1327.1 \\
\hline 8.33 & 0.64 & 1054.2 & 315.0 & 79.8 & 0.0 & 12.0 & 1461.1 \\
\hline 8.9 & 0.81 & 832.4 & 254.7 & 64.5 & 0.0 & 9.7 & 1161.4 \\
\hline 8.9 & 0.75 & 900.6 & 254.7 & 64.5 & 0.0 & 9.7 & 1229.5 \\
\hline 8.9 & 0.69 & 974.4 & 267.5 & 67.8 & 0.0 & 10.2 & 1320.0 \\
\hline 8.9 & 0.64 & 1054.2 & 315.0 & 79.8 & 0.0 & 12.0 & 1461.1 \\
\hline 9.5 & 0.81 & 832.4 & 238.7 & 60.5 & 0.0 & 9.1 & 1140.7 \\
\hline 9.5 & 0.75 & 900.6 & 238.7 & 60.5 & 0.0 & 9.1 & 1208.8 \\
\hline 9.5 & 0.69 & 974.4 & 267.5 & 67.8 & 0.0 & 10.2 & 1320.0 \\
\hline 9.5 & 0.64 & 1054.2 & 315.0 & 79.8 & 0.0 & 12.0 & 1461.1 \\
\hline 10.11 & 0.81 & 832.4 & 225.0 & 57.0 & 0.0 & 8.6 & 1123.0 \\
\hline 10.11 & 0.75 & 900.6 & 225.0 & 57.0 & 0.0 & 8.6 & 1191.1 \\
\hline 10.11 & 0.69 & 974.4 & 267.5 & 67.8 & 0.0 & 10.2 & 1320.0 \\
\hline 10.11 & 0.64 & 1054.2 & 315.0 & 79.8 & 0.0 & 12.0 & 1461.1 \\
\hline
\end{tabular}


$1 \quad$ Table S.4

2 Results of cumulative energy demand for the 5 different sub-systems in each scenario tested.

\begin{tabular}{|c|c|c|c|c|c|c|c|}
\hline \multirow[b]{2}{*}{ TGC } & \multirow[b]{2}{*}{ FCR } & \multicolumn{6}{|c|}{ Cumulative energy demand, $\mathrm{MJ}$} \\
\hline & & $\begin{array}{l}\text { Production } \\
\text { of feed } \\
\text { purchased }\end{array}$ & $\begin{array}{c}\text { Production of } \\
\text { energy expended } \\
\text { on farm } \\
\end{array}$ & $\begin{array}{c}\text { Production of } \\
\text { facilities and } \\
\text { equipment used }\end{array}$ & $\begin{array}{c}\text { Farm } \\
\text { operation }\end{array}$ & $\begin{array}{c}\text { Offsite } \\
\text { waste water } \\
\text { treatment }\end{array}$ & Total \\
\hline 8.33 & 0.81 & 11655.8 & 4452.4 & 926.9 & 0.0 & 127.4 & 17162.5 \\
\hline 8.33 & 0.75 & 12610.2 & 4452.4 & 926.9 & 0.0 & 127.4 & 18116.9 \\
\hline 8.33 & 0.69 & 13644.3 & 4452.4 & 926.9 & 0.0 & 127.4 & 19150.9 \\
\hline 8.33 & 0.64 & 14761.7 & 5137.2 & 1069.4 & 0.0 & 147.0 & 21115.2 \\
\hline 8.9 & 0.81 & 11655.8 & 4153.2 & 864.6 & 0.0 & 118.8 & 16792.5 \\
\hline 8.9 & 0.75 & 12610.2 & 4153.2 & 864.6 & 0.0 & 118.8 & 17746.9 \\
\hline 8.9 & 0.69 & 13644.3 & 4362.4 & 908.2 & 0.0 & 124.8 & 19039.7 \\
\hline 8.9 & 0.64 & 14761.7 & 5137.2 & 1069.4 & 0.0 & 147.0 & 21115.2 \\
\hline 9.5 & 0.81 & 11655.8 & 3891.8 & 810.2 & 0.0 & 111.3 & 16469.1 \\
\hline 9.5 & 0.75 & 12610.2 & 3891.8 & 810.2 & 0.0 & 111.3 & 17423.5 \\
\hline 9.5 & 0.69 & 13644.3 & 4362.4 & 908.2 & 0.0 & 124.8 & 19039.7 \\
\hline 9.5 & 0.64 & 14761.7 & 5137.2 & 1069.4 & 0.0 & 147.0 & 21115.2 \\
\hline 10.11 & 0.81 & 11655.8 & 3668.5 & 763.7 & 0.0 & 105.0 & 16193.0 \\
\hline 10.11 & 0.75 & 12610.2 & 3668.5 & 763.7 & 0.0 & 105.0 & 17147.3 \\
\hline 10.11 & 0.69 & 13644.3 & 4362.4 & 908.2 & 0.0 & 124.8 & 19039.7 \\
\hline 10.11 & 0.64 & 14761.7 & 5137.2 & 1069.4 & 0.0 & 147.0 & 21115.2 \\
\hline
\end{tabular}

